\title{
Prospek Pengembangan Usaha Peternakan Pola Integrasi
}

\author{
Diwyanto K., A. Priyanti dan R.A. Saptati \\ Pusat Penelitian dan Pengembangan Peternakan, Bogor
}

INTISARI

Perkembangan usaha peternakan perlu didukung oleh berbagai sarana produksi, salah satunya adalah ketersediaan pakan. Bahan pakan sumber energi dapat berasal dari jagung, singkong, dedak padi, dedak gandum, sagu dan lain sebagainya, sedangkan bahan pakan sumber protein dapat berasal dari bungkil kedelai, tepung ikan, daun leguminosa, tepung darah dan lain-lain. Bahan pakan berserat seperti rumput, jerami padi, pucuk tebu, kulit buah kakao dan by-product pertanian tanaman pangan lainnya merupakan bahan pakan yang banyak dimanfaatkan untuk ternak ruminansia, seperti sapi, domba atau kambing. Peluang pemanfaatan by-product agribisnis sebagai bahan baku industri pakan ternak akan merupakan tantangan sekaligus peluang dalam optimalisasi sumberdaya lokal yang selama ini belum dimanfaatkan secara efisien dan optimal. Di sisi lain, usaha peternakan (sapi) mengalami kendala dalam hal pengadaan daging dan sapi bakalan. Melalui pendekatan LEISA (low external input sustainable agriculture), setiap ha lahan pertanian dapat menghasilkan pakan untuk memelihara sapi sebanyak 2-3 ekor/ha. Dalam hal ini ternak sapi berperan sebagai 'pabrik kompos' dengan bahan baku 'limbah' tanaman, yang pada akhirnya kompos tersebut dipergunakan sebagai bahan pupuk organik bagi tanaman. Dalam upaya meningkatkan populasi ternak sapi potong dengan biaya produksi yang layak, pendekatan pola integrasi ternak dengan tanaman pangan, perkebunan dan hutan tanaman industri layak untuk dikembangkan baik secara teknis, ekonomis maupun sosial. Salah satu kunci keberhasilan dari pola ini adalah tidak ada bahan yang terbuang, serta pemanfaatan inovasi secara benar dan efisien. Melalui penerapan pola integrasi tanaman dan ternak melalui pendekatan low external input, menghasilkan produk peternakan berdayasaing. Oleh karenanya ke depan usaha peternakan melalui integrasi sistem usaha dengan tanaman menjadi cukup menarik dan berpeluang cukup baik untuk dilaksanakan.

Kata kunci: sistem integrasi, tanaman-ternak

\section{PENDAHULUAN}

Sektor pertanian saat ini masih menjadi andalan utama dalam pembangunan nasional, terkait dengan upaya untuk mewujudkan dan mempertahankan ketahanan pangan, menyediakan lapangan kerja dan kesejahteraan masyarakat, serta memenuhi berbagai kebutuhan bahan baku industri. Akan tetapi beras masih merupakan komoditas paling penting sebagai makanan pokok penduduk Indonesia, sehingga sistem usaha budidaya padi berperan strategis dalam pemantapan ketahanan pangan. Sistem usaha budidaya padi juga menciptakan lapangan kerja dengan melibatkan tenaga kerja mencapai 39,9 juta (Departemen Pertanian, 2004). Usaha ini memberikan nilai tambah yang relatif cukup besar karena sampai saat ini usahatani padi mempunyai peran yang paling dominan dalam sektor pertanian. Peran sosial ekonomi yang sedemikian besar dari komoditas ini telah menempatkan pembangunan sistem usaha budidaya padi merupakan agenda kebijakan nasional yang senantiasa mendapatkan prioritas penanganan pemerintah. 
Pelaksanaan berbagai program pembangunan tersebut mampu mendorong peningkatan produksi padi, meskipun pada tingkat laju pertumbuhan yang semakin melandai (Tabel 1). Produksi padi pada tahun 2003 mencapai 52.14 juta ton gabah kering giling, atau meningkat sekitar 1,26\% dibandingkan produksi tahun 2002, sedangkan hal tersebut untuk produktivitas padi naik sebesar 1,54\% (Badan Pusat Statistik, 2003). Yang perlu diwaspadai adalah terjadinya kecenderungan penurunan luas panen sebagai akibat dari pengurangan luas lahan sawah karena konversi ke penggunaan non pertanian. Dengan luas pemilikan lahan petani yang relatif sempit, maka pendapatan dari usahatani padi tidak dapat mencukupi kebutuhan rumahtangga petani. Oleh karena itu, upaya peningkatan produktivitas dan produksi padi tidak dapat terlepas dari upaya diversifikasi usaha di perdesaan, stabilisasi harga gabah, perlindungan petani melalui kebijakan impor beras serta pengentasan kemiskinan dan penanganan masalah kerawanan pangan di pedesaan.

Tabel 1. Perkembangan Luas Panen, Produksi dan Produktivitas Padi

\begin{tabular}{cccc}
\hline \hline Tahun & $\begin{array}{c}\text { Luas panen } \\
\text { (juta ha) }\end{array}$ & $\begin{array}{c}\text { Produksi } \\
\text { (juta ton) }\end{array}$ & $\begin{array}{c}\text { Produktivitas } \\
\text { (ton/ha) }\end{array}$ \\
\hline 1999 & 11,96 & 50,87 & 4,25 \\
2000 & 11,79 & 51,90 & 4,40 \\
2001 & 11,50 & 50,46 & 4,39 \\
2002 & 11,52 & 51,49 & 4,47 \\
2003 & 11,49 & 52,14 & 4,54 \\
\hline
\end{tabular}

Sumber : Badan Pusat Statistik, 2003

Adiningsih (2000) menyatakan bahwa salah satu upaya untuk meningkatkan produktivitas tanaman pangan selama ini lebih banyak dilakukan pada lahan subur beririgasi melalui peningkatan mutu intensifikasi, diantaranya dengan meningkatkan penggunaan pupuk anorganik. Hal ini diduga dapat memberikan indikasi kecenderungan menurunnya kesuburan lahan pertanian karena kurangnya bahan organik. Salah satu cara untuk mengembalikan kesuburan lahan adalah melalui perbaikan struktur tanah dan pemenuhan mikroba tanah dengan menggunakan pupuk/bahan organik. Lebih lanjut dilaporkan bahwa kebutuhan ideal bahan organik di dalam tanah adalah sekitar $2 \%$, sedangkan bahan organik saat ini yang tersedia kurang dari $1 \%$. Perkembangan ini memberikan peluang bagi pengembangan usaha peternakan untuk mengatasi masalah kondisi kesuburan tanah melalui inovasi teknologi pemanfaatan kotoran ternak sebagai bahan dasar pembuatan kompos. Limbah hasil pertanian yang sangat potensial, dalam hal ini jerami padi, di sisi lain juga dapat menjadi sumber pakan berserat bagi usaha peternakan sapi. Kedua masalah tersebut diatas, yaitu : kecenderungan menurunnya tingkat kesuburan lahan karena terbatasnya kandungan bahan organik tanah, dan kurangnya pasokan daging atau sapi bakalan, dapat diatasi secara simultan yaitu dengan menerapkan pola integrasi tanaman dan ternak melalui pendekatan low external input. Pola integrasi ini merupakan penerapan usaha terpadu antara komoditas tanaman, dalam hal ini padi, dan komoditas peternakan (sapi), dimana jerami padi digunakan sebagai pakan ternak sapi penghasil sapi bakalan, dan kotoran ternak sebagai bahan utama pembuatan kompos dimanfaatkan untuk pupuk organik yang dapat meningkatkan kesuburan lahan. Pendekatan low external input adalah suatu cara dalam menerapkan konsep pertanian terpadu dengan mengupayakan penggunaan input yang berasal dari sistem pertanian sendiri, dan sangat minimal penggunaan input produksi dari luar sistem pertanian tersebut. 
Konsep pola integrasi tanaman-ternak dan pengalaman empiris di lapang terdapat benang merah yang dapat ditarik, yaitu (1) petani (padi) termotivasi untuk mempertahankan kesuburan lahan pertanian dengan cara memperbaiki pola budidaya dan mempertahankan kandungan bahan organik, (2) penggunaan pupuk kimia dilakukan secara benar dan diimbangi dengan penambahan pupuk organik, (3) penggunaan kompos membuka peluang pasar baru dan mendorong masyarakat perdesaan untuk mengembangkan industri kompos dengan memelihara ternak (sapi), (4) teknologi pakan dalam memanfaatkan jerami padi dan limbah pertanian lainnya telah mampu mengurangi biaya pemeliharaan sapi melalui usaha kompos, (5) anak sapi (pedet) merupakan produk utama dari budidaya sapi, namun sebagian biaya pakan dapat diatasi dengan penjualan kompos, dan (6) peternakan dapat dipandang sebagai usaha investasi (tabungan) yang tidak terkena inflasi, mampu menciptakan lapangan kerja yang memang tidak tersedia di perdesaan, dan menjadi bagian integral dari sistem usahatani dan kehidupan masyarakat (Diwyanto et al., 2002).

\section{POTENSI PENGEMBANGAN INTEGRASI TANAMAN -TERNAK}

Beberapa potensi yang ada dan dapat digunakan untuk pengembangan usaha peternakan sapi potong terintegrasi di Indonesia antara lain: (1) adanya pasar domestik yang potensial, (2) daya dukung lahan/alam untuk menyediakan pakan ternak sangat besar dan relatif murah, (3) sumberdaya manusia dan kelembagaan relatif tersedia, (4) sumberdaya genetik ternak, dan (5) tersedianya inovasi teknologi pola integrasi.

\section{Potensi Pasar}

Jika dilihat dari pangsa konsumsi, sekitar 26,1\% daging yang dikonsumsi adalah daging sapi. Dengan pertumbuhan penduduk sebesar $1,5 \%$ per tahun dan pertumbuhan ekonomi meningkat dari 1,5\% sampai 5\% pada tahun 2005 diperkirakan konsumsi daging sapi akan meningkat dari $1,9 \mathrm{~kg} / \mathrm{kapita} /$ tahun menjadi 2,8 $\mathrm{kg} / \mathrm{kapita} / \mathrm{tahun}$. Jika dikaitkan dengan ketentuan Pola Pangan Harapan, seharusnya konsumsi daging masyarakat Indonesia sebanyak 10,1 kg/kapita/tahun (Riady, 2004).

Indonesia mempunyai lahan persawahan dan perkebunan yang luas, dimana limbah pertanian maupun bio-masa yang dihasilkan dalam industri agribisnis belum sepenuhnya dimanfaatkan sebagai sumber pakan untuk pengembangan sapi maupun ternak ruminansia yang lain. Saat ini masih tersedia kawasan perkebunan yang relatif kosong ternak seluas lebih dari 15 juta ha, lahan sawah dan tegalan yang belum optimal dimanfaatkan untuk pengembangan ternak lebih dari 10 juta ha, serta lahan lain yang belum dimanfaatkan secara optimal lebih dari 5 juta ha di Sumatera, Kalimantan dan Sulawesi. Setiap hektar kawasan perkebunan atau pertanian sedikitnya mampu menyediakan bahan pakan untuk 2 sampai 3 ekor sapi, sepanjang tahun.

Luas lahan pertanian di Indonesia pada tahun 2002 mencapai 46,9 juta ha atau sekitar $74,68 \%$ dari total luas lahan yang ada. Dari jumlah itu sekitar 7,7 juta ha atau $12,36 \%$ adalah lahan persawahan, dan 16,4 juta ha atau 26,10\% lahan perkebunan. Pada umumnya terdapat korelasi yang sangat kuat antara areal sawah dan produksi padi dengan populasi sapi (Tabel 2), kecuali Jawa Barat. Jawa Barat yang merupakan lumbung padi ternyata hanya memiliki sapi potong sekitar 150.000 ekor atau kurang dari $10 \%$ dari populasi sapi di Jawa Timur.

Sementara itu dari luas areal perkebunan rakyat, yang dapat digunakan untuk pengembangan integrasi tanaman ternak saat ini diperkirakan sekitar 10 juta ha, terdiri dari areal tanaman karet 2,8 juta ha, kelapa 3,6 juta ha, kelapa sawit 1,8 juta ha, jambu mete 0,5 juta ha, kakao 0,8 juta ha, cengkeh dan 0,4 juta ha. Dengan asumsi 1 ha areal tanaman perkebunan dapat dimanfaatkan untuk pengembangan 1 ekor ternak ruminansia besar dan sekitar 25\% 
dari areal yang ada dapat digunakan, maka potensinya mencapai 2,5 juta ekor ternak ruminansia besar dapat dihasilkan dari sub sektor perkebunan (Subagyono, 2004). Jumlah ini belum termasuk areal perkebunan besar yang juga cukup potensial. Pemanfaatan potensi lahan perkebunan ini dapat berupa: (a) pemanfaatan lahan diantara tanaman perkebunan (karet, kelapa, kelapa sawit, jambu mete dan cengkeh) untuk penanaman pakan hijauan ternak dan padang penggembalaan ternak serta kandang ternak dan (b) pemanfaatan limbah tanaman pokok dan tanaman sela dan limbah pabrik (kelapa sawit, kelapa dan kakao) sebagai sumber pakan ternak. Pemanfaatan limbah pertanian dan perkebunan yang sedianya terbuang dapat dimanfaatkan sebagai pakan ternak sekaligus membuka peluang pengembangan ternak yang lebih besar.

Tabel 2. Luas Areal Panen Sawah Irigasi, Produksi Padi, Produksi Jerami Padi dan Populasi Sapi di Beberapa Propinsi Tahun

\begin{tabular}{lrrrr}
\hline \hline \multicolumn{1}{c}{ Propinsi } & $\begin{array}{c}\text { Luas Areal } \\
\text { panen } \\
\text { (ha) }\end{array}$ & $\begin{array}{c}\text { Produksi } \\
\text { padi } \\
\text { (ton) }\end{array}$ & $\begin{array}{c}\text { Potensi } \\
\text { produksi } \\
\text { jerami padi } \\
\text { (ton) }\end{array}$ & $\begin{array}{c}\text { Populasi sapi } \\
\text { (ribu ekor) }\end{array}$ \\
\hline DKI Jakarta & 1.724 & 7.140 & 8.620 & - \\
Jawa Barat & 1.676 .506 & 8.842 .234 & 8.382 .530 & 208,9 \\
Jawa Tengah & 1.535 .625 & 8.123 .839 & 7.678 .125 & $1.374,3$ \\
D.I. Yogyakarta & 130.681 & 652.280 & 653.405 & 221,6 \\
Jawa Timur & 1.695 .514 & 8.914 .995 & 8.477 .570 & $3.312,0$ \\
Banten & 348.033 & 1.675 .055 & 1.740 .165 & 9,7 \\
Luar Jawa & 6.089 .274 & 23.863 .287 & 30.446 .370 & $6.269,1$ \\
\hline Indonesia & 11.477 .357 & 52.078 .830 & 57.386 .785 & $11.395,6$ \\
\hline
\end{tabular}

Sumber: Badan Pusat Statistik, 2003

2. Potensi Sumberdaya Manusia Dan Kelembagaan

Ketersediaan sumberdaya manusia (SDM) untuk pengembangan usaha peternakan terintegrasi ini cukup besar, dimana dari sekitar 90,8 juta penduduk yang bekerja, sekitar 40 juta atau 46,26\% bekerja di sektor pertanian (BPS, 2003). Sebagian besar petani peternak sudah ada yang membentuk kelompok-kelompok tani ternak sehingga memudahkan dalam pelaksanaan kegiatan penyuluhan maupun pelayanan IB dan kesehatan hewan lainnya. Petugas fungsional pengawas mutu bibit, penyuluh, pelayanan kesehatan hewan sudah cukup banyak tersebar di seluruh propinsi (Riady, 2004).

\section{Potensi Sumberdaya Genetik Ternak}

Rekomendasi para pakar menyarankan bahwa pengembangan sapi sebaiknya memanfaatkan plasma nutfah (sumberdaya genetik, SDG) lokal, antara lain sapi Peranakan Ongole (PO) atau sapi Bali. Kelebihan sapi lokal terutama sapi Bali antara lain adalah (1) daya adaptasi yang tinggi, (2) daya reproduksi sangat baik, (3) mampu memanfaatkan pakan yang berkualitas 'rendah', (4) kualitas karkas sangat baik, serta (5) mempunyai harga jual yang tinggi. Tetapi sapi Bali juga mempunyai beberapa kelemahan, antara lain (1) kurang responsif bila diberi pakan berkualitas, (2) tidak dapat dipelihara bersama domba karena penyakit MCF, (3) persilangan dengan sapi Bos Taurus menghasilkan jantan yang mandul, serta (4) ukurannya relatif kecil (Talib et al., 2002). Secara umum sapi Bali mempunyai lebih banyak keunggulan teknis maupun ekonomis (Diwyanto et al,. 2004).

4. Ketersediaan Inovasi Teknologi Pola Integrasi 
Pada prinsipnya dalam sistem integrasi tanaman-ternak, teknologi yang diintroduksikan mencakup teknologi pakan, terutama teknologi pengelolaan limbah untuk pakan ternak serta teknologi pengomposan atau pengelolaan kotoran ternak untuk pupuk organik. Inovasi lain yang mendukung keberhasilan pengembangan pola ini antara lain sistem perkandangan dan inovasi veteriner (Diwyanto dan Handiwirawan, 2004).

Kualitas pakan dari limbah pertanian, perkebunan atau agroindustri biasanya 'rendah' dan perlu ditingkatkan (feed enrichment), baik melalui perlakuan fisik (pemotongan, pencacahan, pengeringan), kimiawi (amonisasi dengan penambahan urea) dan biologis (penambahan mikroba atau fermentasi). Teknologi yang tersedia saat ini memungkinkan untuk dilakukan penyediaan pakan dalam jumlah yang memadai untuk disimpan sepanjang tahun. Limbah dengan kandungan protein rendah dapat ditambahkan suplemen protein dari limbah pertanian lain atau leguminosa yang kemudian disusun menjadi ransum yang serasi. Penelitian berbagai teknik untuk meningkatkan nilai manfaat nutrisi jerami padi telah dilakukan, antara lain melalui proses amoniasi, hidroksidasi dan fermentasi. Perlakuan urea pada jerami padi dapat meningkatkan kandungan nitrogen jerami padi sekaligus meningkatkan kecernaan, sedangkan fermentasi jerami padi terbuka dengan penambahan probiotik dan urea. Dengan cara ini kandungan protein dapat meningkat dari 3,5 menjadi $7 \%$ dan daya cerna meningkat dari 28 sampai $30 \%$ menjadi 50 sampai 55\%.

Kondisi di lapang saat ini menunjukkan bahwa diantara kotoran ternak yang dihasilkan, sebagian besar petani lebih menyukai kotoran ayam. Sedangkan kotoran sapi banyak digunakan sebagai bahan campuran pembuatan kompos dengan bahan lain. Pada Tabel 3 disajikan populasi ternak di Indonesia dan estimasi produksi kotorannya.

Ternak sapi dewasa, kuda, dan kerbau dapat memproduksi kotoran lembab ratarata seberat $9 \mathrm{~kg} / \mathrm{ekor} / \mathrm{hari}$, sedangkan kambing dan domba rata-rata $1 \mathrm{~kg} / \mathrm{ekor} /$ hari. Berdasarkan data ini maka dalam waktu satu tahun akan diproduksi kotoran ternak sapi, kuda, kerbau, kambing dan domba sebanyak 53,53 juta ton. Bila lahan pertanian memerlukan pupuk kandang 5 sampai 10 ton/ha, maka kotoran ternak tersebut dapat digunakan untuk memupuk 5,3 sampai 10,7 juta ha.

Tabel 3. Populasi Ternak Menurut Jenisnya dan Estimasi Produksi Kotorannya Pada Tahun 2004

\begin{tabular}{llrc}
\hline \hline No. & \multicolumn{1}{c}{ Jenis ternak } & Jumlah (ekor) & $\begin{array}{c}\text { Kotoran ternak lembab } \\
\text { (juta ton/ha) }\end{array}$ \\
\hline 1. & Sapi perah dan potong & 11.108 .000 & 35,99 \\
2. & Kerbau & 2.572 .000 & 8,33 \\
3. & Kuda & 432.000 & 1,40 \\
4. & Kambing & 13.442 .000 & 4,84 \\
5. & Domba & 8.245 .000 & 2,97 \\
\hline & & & 53,53 \\
\hline
\end{tabular}

Sumber: Ditjen Bina Produksi Peternakan, 2004

\section{PROSPEK PENGEMBANGAN INTEGRASI TANAMAN-TERNAK}

1. Sektor Hulu

Biaya terbesar untuk menghasilkan sapi bakalan atau daging adalah pakan, yang dapat mencapai 70 sampai $80 \%$. Dengan pola integrasi, biaya pakan usaha cow calf operation dapat dikurangi secara signifikan, sehingga produk yang dihasilkan mempunyai daya saing yang sangat tinggi. Dengan kelimpahan biomassa yang berasal dari limbah atau hasil samping pertanian/ 
perkebunan maupun agro-industri, biaya untuk penggemukan sapi di Indonesia saat ini sangat kompetitif (Rp. 4 sampai 6 $\mathrm{ribu} / \mathrm{kg} \mathrm{BB}$ ). Inovasi teknologi pakan murah yang dikembangkan Balai Penelitian Ternak dan Loka Penelitian Sapi Potong Grati, telah membuktikan hal tersebut.

Usaha agribisnis hulu yang perlu dikembangkan adalah penyediaan caloncalon induk dan pejantan unggul, baik untuk keperluan IB maupun pejantan untuk kawin alam. Usaha peternakan sapi yang sangat intensif di Jawa, Bali dan Lombok memungkinkan untuk dilakukan aplikasi IB secara lebih luas, baik dengan menggunakan semen beku (frozen semen) maupun semen cair (chilled semen). Namun ketersediaan pejantan untuk 'menyapu' betina yang masih birahi tetap diperlukan. Dan yang lebih penting lagi adalah bangsa (breed) sapi yang akan digunakan harus sesuai dengan program breeding yang ditetapkan, bukan mengarah pada sistem up grading.

Untuk menjamin sapi dapat berkembang dengan baik dan dapat terhindar dari ancaman penyakit berbahaya, diperlukan ketersediaan vaksin dan obat yang memadai. Biaya untuk kesehatan hewan idealnya tidak boleh melebihi 2-5 persen dari total biaya produksi (Rp. 50-100 juta untuk setiap 1000 ekor sapi), namun bila hal ini tidak mendapat perhatian tidak menutup kemungkinan akan terjadi kerugian yang sangat besar (fatal). Biasanya usaha pencegahan yang harus mendapat perhatian, karena akan membutuhkan biaya yang relatif lebih kecil. Untuk keperluan itu fasilitas atau laboratorium yang saat ini sudah ada harus dioptimalkan, termasuk peralatan dan SDM-nya.

\section{Sektor Budidaya}

Diwyanto dan Haryanto (2003) mengemukakan bahwa pada umumnya integrasi ternak dengan tanaman, baik itu tanaman pangan, tanaman perkebunan maupun hortikultura memberikan nilai tambah yang cukup tinggi. Kontribusi ternak di dalam sistem tanaman-ternak bervariasi dari 5 sampai $75 \%$ tergantung pola integrasi yang diterapkan. Tabel 4 memperlihatkan kontribusi ternak di dalam sistem integrasi tanaman-ternak.

Tabel 4. Perkiraan Kontribusi Ternak Dalam Sistem Tanaman-Ternak Terhadap Pendapatan Petani

\begin{tabular}{|c|c|}
\hline Sistem Tanaman-Ternak & Kontribusi ternak $(\%)$ \\
\hline Tanaman pangan - Ayam ${ }^{1)}$ & 17,6 \\
\hline Tanaman pangan + perkebunan - Kambing ${ }^{1)}$ & 16,2 \\
\hline Tanaman pangan - sapi ${ }^{1)}$ & 13,9 \\
\hline Tanaman pangan - ayam+kambing+sapi ${ }^{1)}$ & 35,2 \\
\hline Tanaman pangan + perkebunan - ayam + kambing + sapi ${ }^{1)}$ & 34,9 \\
\hline Tanaman sayuran - domba ${ }^{2)}$ & 10,4 \\
\hline Kelapa sawit - domba ${ }^{3)}$ & $5-10$ \\
\hline Karet - domba ${ }^{3)}$ & $15-20$ \\
\hline Kelapa - sapi ${ }^{3)}$ & 75 \\
\hline Kelapa - domba ${ }^{3)}$ & 50 \\
\hline
\end{tabular}

Sumber: ${ }^{\text {I) }}$ Sabrani et al. (1992)

2) Sugandi et al. (1992)

3) Iniguez

Usaha integrasi sapi dikaitkan dengan persawahan, perkebunan, padang penggembalaan dan kawasan HTI paling ideal untuk pengembangan usaha cow-calf dan

Sanchez

operation. Secara tradisional, pola integrasi telah diaplikasikan oleh peternak, sehingga usaha cow-calf operation akan terus bertahan. Melalui pola ini dimungkinkan 
untuk mengurangi biaya produksi (pakan) dengan memperoleh tambahan pendapatan dari kompos. Pemanfaatan limbah pertanian untuk menyediakan pakan lengkap dengan harga relatif terjangkau (skala komersial) telah diawali oleh Lolit Sapi Potong Grati, sementara kotoran yang telah diolah menjadi pupuk organik bernilai sekitar Rp. 400/kg (usaha di Solo dan Sukabumi). Pemeliharaan secara kelompok pola integrasi ini memungkinkan keluarga petani memelihara sapi sampai 20 ekor induk (Sukamandi), karena (1) kemudahan penyediaan dan pemberian pakan dan murah, (2) perawatan dan manajemen kandang maupun perkawinan lebih praktis dan efisien, serta (3) upaya menjaga kesehatan ternak dapat dilakukan dengan mudah dan murah (Priyanti dan Djajanegara, 2004).

\section{Sektor Hilir}

Industri hilir yang dapat dikembangkan untuk menunjang usaha sapi potong adalah tersedianya fasilitas Rumah Potong Hewan (RPH) dan tempat penyimpanan produk yang memadai. RPH yang saat ini sudah ada perlu dioptimalkan penggunaannya, sedangkan pembangunan RPH baru harus dilakukan secara selektif agar dapat berjalan dengan baik. Industri pengolahan kompos juga merupakan peluang tersendiri, walaupun investasi dan inovasinya tidak terlampau sulit, dengan perkiraan investasi sekitar Rp. 1 sampai 1,5 milyar per 1000 ekor sapi. Pengembangan sapi pola integrasi sangat memerlukan dukungan dalam pengolahan kompos, karena nilai kompos yang dihasilkan diharapkan dapat mencukupi kebutuhan eksternal input yang harus dibayar.

\section{KESIMPULAN}

Sistem tanaman-ternak dapat diadopsi oleh petani secara berkelanjutan apabila mampu memberikan keuntungan bagi mereka, terutama dalam hal peningkatan pendapatan maupun memperbaiki kesejahteraan mereka. Peningkatan pendapatan dapat diperoleh dengan dua cara, yaitu meningkatkan harga jual (dengan meningkatkan mutu), atau dengan menekan biaya produksi, melalui efisiensi. Dengan rendahnya biaya produksi, setiap produk akan mampu bersaing dengan produk sejenis yang biaya produksinya lebih tinggi. Disamping itu pendapatan dan kesejahteraan petani akan meningkat sebagai akibat terciptanya lapangan kerja baru, baik secara on-farm maupun off-farm. Pola CLS secara empiris telah membuktikan mampu menciptakan lapangan kerja yang bersumber pada usaha dengan memanfaatkan sumberdaya lokal secara lebih efisien.

Pengalaman empiris dan hasil pengkajian di beberapa propinsi telah memberi indikasi bahwa pengembangan sapi pola integrasi telah berhasil cukup baik. Salah satu kunci keberhasilan dari pendekatan ini adalah (1) pemberdayaan petani, (2) inovasi teknologi integrasi tanaman-ternak dan CLS (fermentasi, amoniasi dan pengomposan), (3) dukungan kelembagaan, serta (4) kerjasama.

\section{DAFTAR PUSTAKA}

Adiningsih, S. J. 2000. Peranan bahan organik tanah dalam sistem usahatani konservasi. Dalam: Bahri et al., (eds). Materi Pelatihan Revitalisasi Keterpaduan Usaha Ternak dalam Sistem Usaha Tani. Pusat Penelitian dan Pengembangan Peternakan, Bogor.

Badan Pusat Statistik. 2003. Statistik Indonesia 2003. Biro Pusat Statistik, Jakarta.

.Departemen Pertanian. 2004. Statistik Pertanian 2004. Pusat Data dan Informasi Pertanian, Departemen Pertanian, Jakarta.

Diwyanto, K. dan E. Handiwirawan. 2004. Peran Litbang dalam mendukung usaha agribisnis pola integrasi tanaman-ternak. Prosiding Seminar Nasional Sistem Integrasi TanamanTernak. Denpasar 20-22 Juli 2004. Pusat Penelitian dan Pengembangan 
Peternakan, Balai Pengkajian Teknologi Pertanian Provinsi Bali dan Crop-Animal System Research Network (CASREN), Bogor.

Diwyanto, K., D. Sitompul, I. Manti, I W. Mathius dan Soentoro. 2004. Pengkajian pengembangan usaha sistem integrasi kelapa sawit-sapi. Prosiding Lokakarya Nasional Sistem Integrasi Kelapa Sawit-Sapi. Bengkulu, 9-10 September 2003. Badan Penelitian dan Pengembangan Pertanian, Pemerintah Propinsi Bengkulu dan PT. Agricinal, Bogor.

Diwyanto, K., B.R. Prawiradiputra dan D. Lubis. 2002. Integrasi tanaman-ternak dalam pengembangan agribisnis yang berdaya saing, berkelanjutan dan berkerakyatan. Buletin Ilmu Peternakan Indonesia, Wartazoa. Volume 12 Nomor 1. Pusat Penelitian dan Pengembangan Peternakan, Bogor.

Iniguez, L. C. and M. D. Sanchez. 1990. Integrated Tree Cropping and Small Ruminant Production Systems. Proceedings of a Workshop on Research Methodologies, Medan. September 9-14, 1990.

Priyanti, A. dan A. Djajanegara. 2004. Pengembangan usaha sapi potong pola integrasi. Prosiding Lokakarya Nasional Sapi Potong: Strategi pengembangan sapi potong dengan pendekatan agribisnis dan berkelanjutan. Yogyakarta 8-9 Oktober 2004. Pusat Penelitian dan Pengembangan Peternakan, Bogor.

Riady, M. 2004. Tantangan dan peluang peningkatan produksi sapi potong menuju 2020. Prosiding Lokakarya Sapi Potong: Strategi pengembangan sapi potong dengan pendekatan agribisnis dan berkelanjutan. Yogyakarta 8-9 Oktober 2004. Pusat Penelitian dan Pengembangan Peternakan, Bogor.

Sabrani, M., B. Sudaryanto, A. Prabowo, A. Tikupadang dan A. Suparyanto. 1992. Dampak integrasi ternak dalam usahatani terhadap pendapatan. Prosiding Agro-Industri Peternakan di Perdesaan. Ciawi, Bogor, 10-11 Agustus 1992. Balai Penelitian Ternak, Bogor.

Subagyono. 2004. Prospek pengembangan ternak pola integrasi di kawasan perkebunan. Prosiding Seminar Nasional Sistem Integrasi TanamanTernak. Denpasar 20-22 Juli 2004. Pusat Penelitian dan Pengembangan Peternakan, Balai Pengkajian Teknologi Pertanian Provinsi Bali dan Crop-Animal System Research Network (CASREN), Bogor.

Sugandi, D., U. Kusnadi dan M. Sabrani. 1992. Integrasi ternak domba dalam sisitem usahatani sayuran di dataran tinggi Wonosobo. Prosiding AgroIndustri Peternakan di Perdesaan. Ciawi, Bogor, 10-11 Agustus 1992. Balai Penelitian Ternak, Bogor.

Talib, C., K. Entwistle, A. Siregar, S. Budiarti-Turner dan D.R. Lindsay. 2003. Survey of population and production of Bali cattle and existing program in Indonesia. In: K. Winstle and D.R. Lindsay (eds). Strategies to Improve Bali Cattle in Eastern Indonesia. ACIAR Proceedings No. 110. 